\title{
The effectiveness of the Wringin Anom Sugar Factory (PG) farmer partnership in Situbondo Regency
}

\author{
WS Untari ${ }^{1^{*}}$ and S Sari ${ }^{1}$ \\ ${ }^{1}$ Program Studi Agribisnis, Fakultas Pertanian Universitas Abdurachman Saleh, \\ Situbondo,Indonesia \\ *Corresponding author: wsuntari@gmail.com
}

\begin{abstract}
This study aims to determine the partnership pattern, determine the effectiveness of the partnership program, determine the level of welfare of partner sugarcane farmers and determine the relationship between the effectiveness of the PG Wringin Anom partnership program with the welfare of sugarcane farmers in Situbondo Regency. The basic method of research used is descriptive method. The research location is PG Wringin Anom. The determination of the number of samples followed the normal distribution rules, amounting to 30 respondents. To analyze the effectiveness of the partnership program between PG Wringin Anom and sugarcane farmers, the interval width formula was used and to analyze the relationship between the effectiveness of the partnership, the Spearman rank correlation test was used through the SPSS 16.0 For Windows Program. The results showed that the partnership pattern that existed between PG Wringin Anom and sugar cane farmers was TRKSU B which was included in the sub-contract partnership pattern. The KKPE program that has been implemented so far has been quite effective, the profit sharing system that has been implemented so far has been quite effective and the assistance program for sugarcane cultivation that has been implemented so far has been quite effective. There is a significant relationship between the effectiveness of the KKPE program on the household welfare of sugar cane farmers, there is a significant relationship between the effectiveness of the profit sharing system on the household welfare of sugar cane farmers
\end{abstract}

\section{Introduction}

Sugar is a strategic commodity because it is consumed by all levels of society whose exploitation comes from on-farm (sugarcane cultivation on land) to off-farm (sugarcane processing in factories). The sugar commodity is also multidimensional in terms of technical, social, economic and political aspects. Technically, sugar cane-based procurement is related to sugarcane cultivation and the technology used in sugarcane processing in sugar factories. [1], from a social perspective, sugar is one of the basic needs of the community and the sugar industry is also closely related to local resources. From an economic perspective, the sugar industry is a source of income for sugarcane farmers and provides jobs for the surrounding community.

The decline in national sugar production is a complex result, from a technological, economic and socio-cultural perspective [2]. From an economic point of view, the lack of capital for farmers and coupled with the frequent delays in credit disbursement has further increased the quality of sugarcane cultivation by farmers. Technically, the decline in sugar production is due to low land productivity and low efficiency of domestic sugar factories, which in turn will result in low competitiveness of 
domestic sugar in the international sugar market. Meanwhile, from a socio-cultural perspective, the level of trust of farmers in sugar factories has decreased.

Wringin Anom Sugar Factory (PG) is one of the sugar factories located in the Situbondo area. PG Wringin Anom in running its business forms a partnership program with sugar cane farmers. The ideal relationship that exists in the partnership itself is a mutually beneficial relationship. In this case, sugarcane farmers need capital and technology assistance, while PG Wringin Anom requires sufficient and sustainable raw materials. Every year the number of partner farmers or smallholder sugarcane from PG Wringin Anom has increased, until there in 2018 the number reached 70 farmers.

The increase in the number of sugarcane farmers who are in partnership with PG Wringin Anom can indicate that the partnership has a positive impact on sugarcane farmers in Situbondo Regency, one of which is that it can provide welfare guarantees for sugarcane farmers in Situbondo Regency. This is reinforced by the increase in sugarcane area of partner farmers in Situbondo Regency. The following is a table of sugarcane area from partner farmers in Situbondo Regency:

Table 1. Area of Smallholder Sugarcane Plantations in Situbondo District

\begin{tabular}{ccc}
\hline Year & Area (Ha) & $\begin{array}{c}\text { Enhancement } \\
(\%)\end{array}$ \\
\hline 2014 & & - \\
\hline 2015 & $2,814.6$ & 19.4 \\
\hline 2016 & $3,494.1$ & 20.5 \\
\hline 2017 & $3,629.3$ & 7,2 \\
\hline 2018 & $4,042.8$ & 4,2 \\
\hline
\end{tabular}

Source: Secondary Data Analysis

Based on this table, it is known that the area of partner farmers' sugarcane plantations from 2014 to 2018 has always increased. The increase in area is due to the increasing number of sugarcane farmers in Situbondo Regency who are starting to become aware of the prospects for sugarcane farming. In addition, the motivation of farmers to partner up is increasing along with the increasing price of sugar.

Based on this background, the researchers are interested in conducting a study entitled: "The Effectiveness of the Wringin Anom Sugar Factory Sugar Factory (PG) Farmer Partnership in Situbondo Regency". Based on the background above, the problems raised in this study are: first, What is the partnership pattern between PG Wringin Anom and sugar cane farmers in Situbondo Regency?. Second, How is the effectiveness of the partnership program between PG Wringin Anom and sugar cane farmers in Situbondo Regency?

\section{Material and Method}

\subsection{Basic Research Method}

The basic method of research used in this research is descriptive method. The descriptive method is a method of examining the status of a human group, an object, a set of conditions, a system of thought, or a class of events at present or at least within a period that is still within the reach of the respondent's memory [3]. The research technique used is survey technique, which is research that takes a sample from a population using a questionnaire as a tool to collect data [4].

\subsection{Research sites}

The research location is PG Wringin Anom in Situbondo Regency based on the consideration that there is a partnership between the Wringin Anom Sugar Factory and Sugar Cane Farmers, as well as the availability of PG Wringin Anom and Sugarcane Farmers in Situbondo Regency to provide information and data needed for research. 


\subsection{Population and Sample Determination Techniques}

The population of this study were sugarcane farmers in 7 areas chaired by a garden cinder in each area or what is known as the Regional Head Sinder (SKW). The determination of the number of samples followed the normal distribution rules, amounting to 30 respondents $(\geq 30)$. The number of samples taken from 7 regions is randomly proportional (Proportional Random Sampling), which is calculated using the formula:

$$
n i=\frac{\mathrm{nk}}{\mathrm{N}} \times \mathrm{n}
$$

\section{Information:}

ni: the number of samples taken in each region

nk: the number of sugarcane farmers from each region

$\mathrm{N}$ : total population of sugarcane farmers from all over the region

$\mathrm{n}$ : number of sugarcane farmers

Table 2. Determination of Number of Respondents

\begin{tabular}{cccc}
\hline No. & Territory & $\begin{array}{c}\text { Number of } \\
\text { Farmers (people) }\end{array}$ & Number of Samples (people) \\
\hline 1 & SKW O1 & 67 & 6 \\
\hline 2 & SKW 02 & 49 & 4 \\
\hline 3 & SKW 03 & 57 & 5 \\
\hline 4 & SKW 04 & 59 & 5 \\
\hline 5 & SKW 05 & 53 & 5 \\
\hline 6 & SKW 06 & 18 & 2 \\
\hline 7 & SKW 07 & 27 & 3 \\
\hline
\end{tabular}

Source: Realization of Wringin Anom Sugar Mill (Processed), 2019

\subsection{Data Analysis Method}

1. Knowing the PG Wringin Anom partnership pattern with sugarcane farmers in Situbondo Regency.

To find out the partnership pattern of PG Wringin Anom with sugar cane farmers in Situbondo Regency, using descriptive analysis method.

2. Knowing the effectiveness of the partnership program between PG Wringin Anom and sugar cane farmers in Situbondo Regency. The effectiveness of the partnership program between PG Wringin Anom and sugarcane farmers is categorized into 3 categories, namely effective, moderately effective, and ineffective. To analyze the effectiveness of the partnership program between PG Wringin Anom and sugarcane farmers, the interval width formula is used, namely:

$$
\text { Interval Width (1) }=\frac{\text { the highest number of scores }- \text { lowest amount }}{\text { number of classes }}
$$

3. The effectiveness ratio uses a simple statistical method with the following formula [5] :

$$
\text { Effectiveness }=\frac{\text { Realisation }}{\text { Target }} \times 100 \%
$$

Target Measurement of the level of effectiveness on the input, process and output variables is carried out on each indicator

\section{Results and Discussion}

Agricultural business partnership is an instrument of cooperation which refers to the creation of an atmosphere of balance, harmony, and skills based on mutual trust between partner companies and 
groups through the realization of a partnership synergy, namely the realization of mutual relationships need, mutual benefit, and reinforce each other [6]. Partnership is also defined as a business strategy carried out by both parties or more within a certain period of time to achieve mutual benefit under the principle of mutual need and mutual benefit bringing up [7].

The partnership program between PG Wringin Anom and sugar cane farmers in the TRKSU B partnership scheme includes the KKPE program, profit sharing and sugarcane cultivation assistance. In each partnership program that is implemented, there is an agreement or agreement that must be implemented and obeyed by both parties. This is also in accordance with the principle of the subcontract partnership pattern, in which PG Wringin Anom seeks to improve the ability of partner groups to implement and comply with partnership agreements.

\subsection{Food and Energy Security Credit Program (KKPE)}

Food and Energy Security Credit, hereinafter referred to as KKPE, is an investment credit and / or working capital provided in the context of supporting the implementation of food security programs and development programs for biofuel raw material plants. The food security program is an effort to increase the production and productivity of food crops, horticulture, animal husbandry and plantation businesses that produce vegetable and / or animal food [8].

KKPE at PG Wringin Anom is intended to help partner farmer capital with subsidized interest rates so that farmers can develop their sugarcane farming business properly. This is in accordance with the principle of the sub-contract partnership pattern, which is to cultivate the capital of the partner group. The main problem for sugarcane farmers is the problem of capital, so that KKPE is needed by farmers to be carried out properly, so the results will be good so that they can continue to guarantee the supply of the main raw material for PG Wringin Anom.

The KKPE implementing banks in PG Wringin Anom include BRI Banks that have been appointed by the Board of Directors with a predetermined number of ceilings. The interest rate from KKPE itself is $7.5 \%$ per year so that the farmers get a subsidy of $4.5 \%$ per year from the normal interest rate $(12 \%)$. The maximum area of oetani land that can be assisted by KKPE is $4 \mathrm{Ha}$ with a maximum allocation per Ha of 18 million. In applying for KKPE at PG Wringin Anom itself, farmers must join a farmer group to facilitate their submission because one of the conditions in applying for KKPE funds is joining a farmer group. This is intended to facilitate the distribution of funds and revenue obtained from PG Wringin Anom.

The KKPE application mechanism is that sugarcane farmers through farmer groups must initially submit a KKPE application letter through the Wina Makmur Cooperative accompanied by RDKK, cultivation costs, photocopy of ID card, can be a nominative sugarcane farming consisting of area and name of farmer group, garden picture, and photocopy land certificate. After being approved by the cooperative, these requirements are then passed on to PG Wringin Anom. After that, the requirements at PG Wringin Anom will be examined by the General Manager. If the General Manager has agreed, then the next step is inspection by the head of the plant division. If the requirements have been approved, then an inspection will be carried out by the Regional Head Sinder (SKW) by surveying directly on the farmer's land whether it is true as stated in the KKPE application letter along with the other requirements. If the KKPE application has been approved, then the next step is approval by a notary and submission to the Bank.

\subsection{Profit-sharing system}

The profit sharing system is the sugar yield between PG Wringin Anom and sugar cane farmers. The yield from the profit sharing system can be seen from the sugar crystals produced or commonly referred to as SHS (Superieure Hoofd Suiker) produced by farmers during the milling period. The grinding period usually starts from May 1 to the end of October (5-6 months). During the milling period, farmers deposit their sugarcane to PG to be milled in accordance with the milling capacity set by PG. after it is ground, the SHS will be produced, which will then be auctioned off the price of the SHS. 
The profit sharing system at PG Wringin Anom in accordance with the Decree of PTPN XI.0 / SE / $060 / 2013$ / SL is for yields less than or equal to 6 , the share is $66 \%$ for farmers and $34 \%$ for PG Wringin Anom. Meanwhile, if the yield is more than 6, the excess is $70 \%$ for farmers and $30 \%$ for PG Wringin Anom. The profit sharing is $90 \%$ in cash and $10 \%$ in the form of sugar, which is given during 1 grinding period, which is once a week during the milling period. The distribution of profit in the form of money is not fully given to farmers, but the money has been deducted for KKPE payments that have been borrowed by the farmers.

The slaughtering installment calculation is calculated from the quintal of sugarcane produced, multiplied by the yield, multiplied by the sugar auction price, and multiplied by the number of pieces per quintal. With these installments, it is hoped that the sugar cane farmers can repay their loans at the end of the milling. If it turns out that the sugar cane farmers have not been able to pay off their loans until the end of the mill, this will be an evaluation by PG Wringin Anom to farmers whether the farmer's sugarcane has been sold to other parties or there are other possibilities, for example due to natural factors. In the production sharing system, in addition to receiving revenue from sugar, partner farmers also get revenue from sugar cane drops. Sugarcane drops are a byproduct of the sugar crystallization process.

The profit sharing system is also in accordance with the principle of the sub-contract partnership pattern, namely seeking and achieving economic business scale. The determination of the profit sharing system is an agreement between PG Wringin Anom and sugar cane farmers who are expected to achieve an economic scale of business between the two parties, so that both parties can mutually benefit.

\subsection{Sugarcane Cultivation Assistance}

Sugarcane cultivation assistance is one of the partnership programs conducted by PG Wringin Anom with the aim of providing assistance to farmers so that they can cultivate sugarcane properly so that they can produce high quality sugarcane and the maximum amount. Sugarcane cultivation assistance to PG Wringin Anom is given to partner sugarcane farmers who are partnering with PG Wringin Anom for the first time or will cultivate sugarcane for the first time, which includes the initial land clearing to logging carried out by PLTRI (Intensification of the People's Sugarcane Field Officer). Through PLTRI, partner sugarcane farmers can also discuss the problems they are facing in cultivating sugarcane. Based on this, it can be seen that sugarcane cultivation assistance has fulfilled one of the elements of partnership, namely mutual strengthening, where PG Wringin Anom and sugar cane farmers both carry out business ethics, both have equal rights and foster each other so as to strengthen the sustainability of the partnership. In addition, sugarcane cultivation assistance also fulfills one of the principles of the sub-contract partnership pattern, in which PG Wringin Anom tries to improve the group's ability in terms of business planning.

In general, the problems faced by sugarcane farmers are related to an increasingly scarce workforce, causing high labor wages. Another problem is unpredictable weather, for example, farmers often experience a lack of rain which results in sugarcane on dry land unable to grow well, unsupportive weather also makes sugarcane seeding by farmers difficult. Another problem that is often faced by sugarcane farmers is the lack of adequate facilities such as tractors which still have to be imported from other regions and also lack of fertilizers because the government's target is not sufficient.

The resolution of the problems that the farmers had complained about to PLTRI would then be followed up at the FMPW (Regional Sugar Production Consultative Forum) meeting. FMPW is a discussion forum in resolving cultivation problems faced by farmers in the same area and chaired by a Regional Head Sinder (SWK). After going through FMPW, the results of the discussion in FMPW will be submitted to the FMPG (Sugar Production Deliberative Forum). FMPG is a discussion forum in solving problems faced by all sugar cane farmers who partner with PG Wringin Anom. So far, sugarcane cultivation has only been assisted by PG, while the Plantation Service has only acted as a moderator in sugarcane cultivation. 


\subsection{Effectiveness of the Partnership Program}

The effectiveness of the partnership program is whether the partnership program carried out by PG Wringin Anom and sugarcane farmers is effective or not based on the process of implementing the partnership program that has been running so far. Partnership programs that are studied for effectiveness include KKPE, production sharing systems and cultivation assistance. The aspects assessed in determining the effectiveness of the KKPE program are the ease of administrative procedures in accessing KKPE funds, the appropriateness of the use of KKPE funds and the accuracy of repaying KKPE funds. The aspects that are assessed in determining the effectiveness of the profit sharing system are the suitability of the agreement on the profit sharing system, the transparency of the yield calculation, the timeliness of the income giver from sugar and the timeliness of the distribution of the profit from drops.

The effectiveness of the partnership program between PG Wringin Anom and sugarcane farmers in Situbondo Regency based on the analysis can be seen in table 3 below:

Table 3. Effectiveness of the Partnership Program between PG Wringin Anom and Sugarcane Farmers in Situbondo Regency

\begin{tabular}{|c|c|c|c|c|}
\hline No. & $\begin{array}{l}\text { Partnership Programs and } \\
\text { Categories }\end{array}$ & Score Interval & Number of people) & Percentage (\%) \\
\hline \multirow[t]{4}{*}{1} & KKPE & & & \\
\hline & - Ineffective & $3-5$ & 0 & 0.0 \\
\hline & - Effective enough & $5,1-7$ & 1 & 3,3 \\
\hline & - Effective & $7,1-9$ & 29 & 96.7 \\
\hline \multirow[t]{4}{*}{2} & Profit-sharing system & & & \\
\hline & - Ineffective & $4-6$ & 2 & 6,7 \\
\hline & - Effective enough & $7-9$ & 27 & 90.0 \\
\hline & - Effective & $10-12$ & 1 & 3,3 \\
\hline \multirow[t]{4}{*}{3} & $\begin{array}{l}\text { Sugarcane Cultivation Assistance } \\
\text { - Ineffective }\end{array}$ & & & \\
\hline & - Effective enough & $3-5$ & 6 & 20.0 \\
\hline & - Effective & $5,1-7$ & 20 & 66.7 \\
\hline & & $7,1-9$ & 4 & 13.3 \\
\hline
\end{tabular}

Source: Primary Data Analysis, 2019

a. The effectiveness of the KKPE program on the partnerships made by PG Wringin Anom and sugarcane farmers

KKPE is an aid fund that functions to assist farmers in cultivating sugarcane. The effectiveness of the KKPE program for partnerships is the effectiveness of the KKPE program that has been implemented in the partnership between PG Wringin Anom and sugarcane farmers as seen by the process of implementing the program. The KKPE program implementation process studied concerns the ease of administrative procedures, the appropriateness of the use of KKPE funds and the accuracy of repaying KKPE funds.

Based on the data in table 3, it can be seen that the highest percentage of the effectiveness of the KKPE program against partnerships is $96.7 \%$ or as many as 29 respondents stated that the KKPE program was effective. The second highest percentage was $3.3 \%$ or 1 respondent stated that the KKPE program was quite effective and the smallest percentage was $0 \%$ or there were no respondents who stated that the KKPE program was not effective. Based on this analysis, it can be concluded that the KKPE program that has been implemented so far has been effective.

The administrative procedure for submitting KKPE funds has been easy for all sugarcane farmers, this is because PG always helps farmers if they find it difficult to administer the required KKPE funds. In general, all the requirements needed by farmers in applying for KKPE funds have 
been fulfilled properly. Farmers who have previously applied for KKPE funds and want to apply again in the following year only need to request approval from the urban village. This is because all the administrative requirements in the submission have been assisted by PG.

The use of KKPE funds by most farmers can also be used in accordance with the provisions, namely to be allocated to meet sugarcane cultivation needs. This is because the KKPE funds from the PG are given in stages according to the farmers' needs. KKPE funds are given in 3 stages during one planting season. In addition, the provision of KKPE funds was not fully provided in the form of money but also in the form of fertilizer. However, there are also farmers who do not fully use KKPE funds for sugarcane cultivation needs, this is because farmers are often pressed by the fulfillment of their daily needs so that some of the KKPE funds are used to meet their daily needs. Meanwhile, the fulfillment of sugarcane cultivation often uses other funds outside of KKPE funds.

Repayment of KKPE funds by farmers themselves can also be done in a timely manner. This is because the way to pay off KKPE funds is to cut the income of partner farmers at the time of handing over income from production sharing, which is once a week during the milling period. In addition, PG also tolerates farmers regarding how much income cuts they want. However, according to PG there are also some farmers who have not been able to pay off their KKPE loans at the end of grinding. There are various possibilities for this to happen,

b. The effectiveness of the profit sharing system for the partnerships made by PG Wringin Anom and sugar cane farmers

The effectiveness of the profit sharing system, there is a partnership, is the effectiveness of the profit sharing system that has been implemented in the partnership between PG Wringin Anom and sugarcane farmers which is seen based on the process of implementing the program. The process of implementing the profit sharing system studied concerns the suitability of the profit sharing agreement between PG Wringin Anom and sugar cane farmers, yield transparency, accuracy in submitting income from sugar and from molasses. Based on the data in table 3 , it can be seen that the highest percentage of the effectiveness of the profit sharing system for partnerships is $66.7 \%$ or as many as 20 respondents stated that the profit sharing system was quite effective. The second largest percentage is $20 \%$ or as many as 6 respondents stated that the profit sharing is not effective and the lowest percentage is $13,3 \%$ or as many as 4 respondents stated that the profit sharing system was effective. Based on the results of this analysis, it can be concluded that the profit sharing system implemented so far has been quite effective.

In the production sharing system, it can be implemented in accordance with the stipulated production sharing provisions, namely $66 \%$ for farmers and $34 \%$ for PG. whereas if the yield is more than 6 , the excess is $70 \%$ for farmers and $30 \%$ for PG. however, these production sharing provisions have not been able to fulfill the real wishes of the farmers. In general, farmers want a 70:30 share system where 70\% of the share is for farmers and 30\% for PG. This is because the price of sugar often experiences uncertainty, last year alone, the price of $1 \mathrm{~kg}$ of sugar was Rp. $8,400.00$, whereas according to farmers, if it is calculated with the costs that must be paid, the price of $1 \mathrm{~kg}$ of sugar should have been more than Rp. 9,000.00.

According to most farmers, the yield calculations that have been done by PG Wringin Anom are quite transparent. In general, farmers already know the yield they have produced, although the knowledge of the yield is not certain, but only the average yield has been produced. also farmers who stated that the yield calculations carried out by PG Wringin Anom were not transparent so far. They argue, that the authority to determine the yield is only in the PG laboratory environment, where the farmers do not know at all. There were also farmers who stated that when the sample yield was taken, the yield was high, reaching a number above 7, However, when all the sugar cane is supplied to PG, the yield is low, which is only in the range of number 6. According to farmers there are several possibilities, including due to the low productivity of the factory machinery, namely the old sugarcane pounder so that it cannot be maximally used for pounding. sugarcane in small quantities. In addition, there were also farmers who stated that the determination of yield was not based on the yield obtained by the farmer, but purely on the authority of the PG. 
The timeliness of the delivery of income from sugar so far is quite precise, which is given to farmers once a week during the milling period, although sometimes there is also a delay in providing income from sugar, which is only given to farmers once every two weeks. According to farmers this is due to the sugar stock in There are still many factory investors, so the investors do not directly buy all the sugar from PG and this is what also causes the price of sugar to fall. According to farmers, the abundance of sugar stocks is due to the government importing more sugar rather than increasing domestic sugar production. If in this situation,

Giving income from drops by the PG is set once at the end of the mill. Based on the results of the research, most farmers stated that the timeliness of the delivery of income from molasses at this time is considered not on time. Until now, farmers have not received income from molasses which should have been paid at the end of 2018. According to farmers, this is due to the late payment of funds from investors. If this continues to happen, of course it can have a negative impact on the implementation of partnerships in the future which can make farmers reluctant to partner with PG Wringin Anom because the income is not paid on time.

c. The effectiveness of the sugarcane cultivation assistance program for the partnerships conducted by PG Wringin Anom and sugarcane farmers

The effectiveness of the sugar cane cultivation assistance program on the partnership is whether or not the sugarcane cultivation assistance program is carried out in the partnership between PG Wringin Anom and sugarcane farmers which is seen based on the process of implementing the program. The process of implementing the sugarcane cultivation mentoring program studied concerns whether there is a mentoring schedule, appropriateness of the mentoring material and the implementation of the overall mentoring activity.

Based on the data in table 3, it can be seen that the highest percentage of the effectiveness of the sugarcane cultivation assistance program against partnerships is $90 \%$ or as many as 27 respondents stated that the sugarcane cultivation assistance program was quite effective. The second highest percentage was $6.7 \%$ or as many as 2 respondents who stated that the sugarcane cultivation assistance program was not yet effective and the lowest percentage was $3.3 \%$ or as much as 1 respondent who stated that the sugarcane cultivation assistance program was effective. Based on the results of the analysis, it can be concluded that the sugarcane cultivation assistance program that has been implemented so far has been quite effective.

Sugarcane cultivation assistance by PG Wringin Anom is carried out by PLTRI (Intensified People's Sugarcane Field Officer). There is no definite scheduling of the cultivation assistance carried out. According to farmers, farmers actually do not fully understand how to properly cultivate sugarcane, such as how to choose suitable varieties of sugarcane to plant and how to fulfill sufficient water supply if there is a lack of rain. The assistance provided by PG Wringin Anom includes assistance to farmers from planting to logging, but only when the farmers start a partnership with PG only. Apart from that, PLTRI only occasionally checks farmers' lands to determine when to cut them. right.

Most of the farmers stated that the guidance materials provided by PG were sufficiently in line with the problems faced by farmers. This was because the provision of mentoring materials by PG itself was based on farmers' complaints about sugarcane cultivation. In general, at the end of milling there is a deliberation meeting or FMPG (Sugar Production Deliberative Forum) by representatives of all partner sugarcane farmers together with all regional head cylinders to discuss problems that exist in one sugarcane planting season or discuss all problems that have previously been discussed at FMPW The existing (Regional Sugar Production Deliberative Forum) is generally held once a month.

\section{Conclusions}

Based on the results of research and discussion examining the effectiveness of the partnership between PG Wringin Anom sugarcane farmers in Situbondo Regency, the following conclusions can be drawn: 
First, The partnership pattern that exists between PG Wringin Anom and sugar cane farmers in Situbondo Regency is the People's Sugar Cane Business Cooperation B (TRKSU B) with the principle of a sub-contract partnership pattern. Second, The effectiveness of the partnership between PG Wringin Anom and sugarcane farmers according to the research results can be seen as follows: The KKPE program that has been running so far has been effective, The profit sharing system that has been implemented so far is quite effective, The sugarcane cultivation assistance program that has been running so far has been quite effective.

\section{References}

[1] Marpaung, YTF, Parulian, H, WH, Limbong, Nunung, K. 2011. Development Sugar Industry Indonesia and the urgency of national sugar self-sufficiency. Indonesian Journal of Agricultural Economics (IJAE) Vol / 2, No. 1. Bogor Agricultural University. Bogor.

[2] Widotono, H. 2009. Partnership Model between Sugar Factory Farmers Investors, Alternative National Social Strategy. Hendri-wd.blogspot.com. Accessed on Wednesday, 25 December 2019 at $8.23 \mathrm{WIB}$

[3] Nazir, M. 2005. Research Methods. Ghalia Indonesia. Bogor.

[4] Singarimbun, M and Effendi, S. 1995. Survey Research Methods. LP3ES. Jakarta.

[5] Martodireso, S., Widada, AS. 2001 Terobosan Kemitraan Usaha dalam Era Globalisasi. Yogyakarta: Kanisius.

[6] Martodireso, S., Widada, AS. 2001 Terobosan Kemitraan Usaha dalam Era Globalisasi. Yogyakarta: Kanisius.

[7] Hafsah, Mohammad Jafar. 2000. Kemitraan Usaha: Konsepsi dan Strategi, Jakarta: PT. Pustaka Sinar Harapan.

[8] Ministry of Agriculture. 2000. Business Partnership. West Koya Agricultural Technology Study Workshop. Irian Jaya. 